Strausz László

\title{
Kultúrakutatás, mint retrospektív módszertan
}

\section{Szerzô}

Strausz László (1976) 2001-ben a Pécsi Tudományegyetem filozófia szakán szerzett diplomát. 2001-tôl a Georgia State University doktori ösztöndíjas hallgatója, ugyanezen az egyetemen a második évtốl kezdve folyamatosan tanít. 2007-ben doktori diplomát szerez Communication (Moving Image Studies) szakon, majd a pennsylvaniai Bucknell University-n, utána a londoni University College London-on dolgozik. 2010-tôl az ELTE Filmtudomány Tanszék adjunktusa. Kutatásai a közép-kelet-európai film társadalmi és formai témáira irányulnak. Publikációiban a nemzeti identitás, a mozgóképes sztereotípiák, a kollektív emlékezet és a múltfeldolgozás témáit vizsgálja a kortárs román és a magyar filmek tükrében. 2016 ôsz óta a Studies in Eastern European Cinema (Routledge) folyóirat szerkesztóje. 2017 júniusában jelenik meg Hesitant Histories on the Romanian Screen c. monográfiája a londoni Palgrave Macmillan kiadónál.

https://doi.org/10.31176/apertura.2018.13.1.8 


\section{Strausz László}

\section{Kultúrakutatás, mint retrospektív módszertan}

[Pócsik Andrea: Atkelések. A romaképkészités (an)archeológiája. Budapest, Gondolat Kiadó, 2017.]

Tudományos szövegek beszédmódjáról oktatóként azt tanítjuk diákjainknak, hogy minden akadémiai projektnek világosan ki kell fejtenie saját módszertanát. A módszer-fetisizmus mögött az a jogos elvárás húzódik, hogy kutatásaink összemérhetőek, eredményeik kommunikálhatóak legyenek. A módszer egy olyan segédeszköz, amely segítségével történeti vagy ok-okozati következtetések, összehasonlítások stb. kifejtése során az olvasó nagyjából elôre tudja, hogy mire számítson. Ez leginkább azt jelenti, hogy a szerzô egy falszifikálható kérdést tesz fel, amelyet az elemzési módszerének, valamint a kutatás hipotézisének ismertetése követ. Elvárjuk továbbá, hogy a szerzô kijelölje problémájának hatáskörét, az elemzett példák kiválasztásának mechanizmusait, és azt az egy vagy több elemból álló elméleti modellt, amely a kiválasztott kutatási problémával kapcsolatban a legmegfelelöbbnek látszik. Jól emlékszem még, amikor egy kutatásmódszertan órán egyetemen egyszer feltettem azt a kérdést, hogy mi van az olyan kutatásokkal, amelyek többfajta módszertant használnak. Tanárunk azt mondta: nem érdemes, mert a szakma theoretical whore-nak, tehát elméleti szajhának fog tartani bennünket. A szóban forgó professzor politikatudománnyal, illetve politikai kommunikációval foglalkozott, és nem volt kifejezetten a cultural studies, azaz a kultúrakutatás híve.

A kultúrakutatás pedig pont egy olyan paradigma, amelynek múvelői nem ragaszkodnak a szociológiában vagy az antropológiában, az irodalomelméletben vagy a történelemtudományok eltérô irányzataiban használatos, diszciplínaspecifikus módszerekhez, hanem keverik ezeket. Ebból a hibridből persze sokfajta eredmény származhat. Az elmúlt években hazai és külföldi konferenciákon sok olyan elôadást hallottam, ahol az elôadó a kultúrakutatást egyfajta takaróként használta arra, hogy az egymással a legjobb esetben is csak érintôleges kapcsolatban álló múvészeti, társadalmi vagy intézményes-gazdasági jelenségeket hasonlítson össze, elemezzen. A kultúrakutatás divatja és széleskörú elterjedése sajnos gyakran visszaigazolja David Bordwell 2005ös, Zizekkel kapcsolatos kijelentését: say anything! ${ }^{[1]}$ Módszertan nélkül bármit lehet mondani. Kijelentéseink vagy igazak, vagy nem igazak, de ennek eldöntésében kizárólag a szöveg szerzője által összerakott módszer lehet a segítségünkre.

Ezért a cultural studies területen dolgozó szerzôknek tulajdonképpen nehezebb dolguk van, mert elôre adott sablon nélkül kell metodológiájukat kialakítani. Számomra azok a kultúrakutatási projektek értékesek, azok szolgálnak valóban új tudással, amelyekben a kutatásból magából szervezôdik a módszer, amelyet folyamatosan vissza képes vetíteni tárgyára. Sok esetben elsôre nem világos a metodológia, de a szöveg maga narrálja szabályait, tehát a klasszikus értelemben 
vett foucault-i diszkurzussá válik: nem csak a tárgyáról szól, hanem a tárgyról való beszéd szabályszerúségeirôl is.

\section{Pócsik Andrea}

\section{ÁTKELÉSEK}

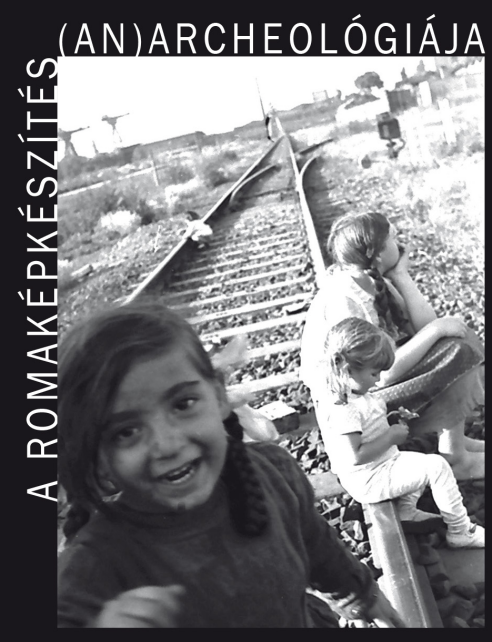

Gondolat

Pócsik Andrea: Átkelések. A romaképkészités (an)archeológiája

Pócsik Andrea idén megjelent kötete remek példa erre a kutatási módszerre, amelynek sajátossága abban ragadható meg, hogy visszamenólegesen, az olvasás folyamata során teszi világossá saját szervező elveit, a fontosabb elméleti fogalmait. Noha Pócsik kötete egy körültekintô bevezetô fejezettel (I. Megközelitóleg: Az elmélettól a gyakorlatig, a tapasztalattól a módszerig és vissza) kezdôdik, ezekben a szövegekben nem kapunk klasszikus értelemben vett módszertani alapvetést, illetve definíciókat: a szerzô inspirációjának forrásairól ír, és olyan fogalmi hálót teremt, amely majd a tulajdonképpeni romakép-elemzésekben, tehát a késôbbi fejezetekben válik világossá a néző számára. Ezek közül kiemelkedôen fontos Danto modell-motívum-téma hármassága, a Trinh T. Minh-ha írásaira visszavezethetố episztemikus ellenállás fogalom, az új filmtörténet-írási módszerként aposztrofált (an)archeológia, valamint az átkelésként magyarított passing-koncepció. Pócsik az első fejezetben megvilágítja ezeknek az elméleti konstrukcióknak a történeti 
beágyazottságát, valamint saját kutatói és oktatói pozíciójának kialakításában betöltött szerepüket, ám itt még csak utal arra, hogy a felvázolt fogalmi háló hogyan fog múködni a hátralevô elemzésekben. A fejezet vége felé világossá teszi, hogy a fogalmi háló összefogásának funkcióját a vizsgált probléma, tehát a romák reprezentációjának, a romaképek emlékezetalakzatként történô elemzésének politikai dimenziója adja:

[e]bben a bevezetô fejezetben a személyes, intellektuális átkelés fázisait ismertettem és értelmeztem, néhány számomra fontos szerzô és a kutatás terepéül szolgáló, Romakép Múhelyben szerzett tapasztalati példák segítségével. A fejezet célja, hogy a felsorakoztatott tevékenységek bemutatásával a következô politikai kérdésben rejlő feszültséget érzékeltesse: egy etnikai kisebbség reprezentációjának kritikai elemzését egy többségi kutató végzi, miközben a jelenlegi társadalmi egyenlôtlenségek felszámolásának egyik legfontosabb kihívása a merev hatalmi viszonyok aláásása. (Pócsik 2017: 45)

Pócsik kutatói pozíciójának kialakításában tehát központi szerepet játszanak az emlékezetpolitikai alakzatok, de ezek a kötetben gyakran (pl. 31, 48) szembe vannak állítva a szerzói-formai elemzési módszerekkel. Ezzel az éles különbségtétellel nem értek egyet: a kettô nem mond ellent egymásnak, ahogy a kötet állítja, sokkal inkább kiegészítik egymást. Az emlékezeti alakzatok is olyan szimbólumok, amelyek politikai szemantikáját elemzés tárgyává kell tennünk. 
Módszertanilag talán a kötet legizgalmasabb kérdése (amelyre Pócsik már a bevezetô fejezetben is utal) az egymástól idôben, térben vagy kulturálisan távolálló szövegek párbeszédbe helyezése. Rögtön a kötet második fejezetében (II. Berlin, 1932) láthatóvá válik ez a probléma: itt az elemzések Moholy-Nagy László és Balázs Béla 1932-es berlini tartózkodásuk alatt készült munkáit vizsgálják, amelyeket a romaképek állítanak élesre. Moholy-Nagy a német fôvváros peremvidékein élô cigányokról forgatott munkái Balázs Leni Riefenstahllal együtt írt forgatókönyvének tükrében mutatják meg a modell-motívum-téma, az (an)archeológia és az átkelés fogalmainak „hatáskörét”. Míg az elôbbi városi dokumentumfilmek formailag, narrációs technikáikat tekintve messze állnak az utóbbi, játékfilmes múfaji jegyekkel operáló Kék fény (Das blaue Licht. Leni Riefentsahl ésBalázs Béla, 1932) cigány hôsnôjének történetétôl, a filmek Pócsik elemzésében a szerzőikátkelésének bizonyítékaivá válnak: Moholy-Nagynál a formai kísérletezéstôl a hangsúlyosabbtársadalmi érzékenység felé, Riefenstahl esetében a múfaji jegyek politikailag túlterhelt,propagandisztikus felhasználása felé való elmozdulás lesz az irány. És hogy mi a kapcsolat e kéttranszformáció között? A szerző arra mutat rá, hogy az átkelések alapjául mindkét esetben aroma/cigány szereplôk ábrázolása szolgál. Egy olyan összefüggésre mutat rá a komparatívelemzés, amelyben két ellentétes célú elmozdulás történeti egybeesése révén explikálja akisebbség-reprezentáció politikai problémáit. Ez a kapcsolat maga az (an)archeológiai módszer.Ahogy korábban utaltam rá, a kötet módszertani- és szelekciós mechanizmusai magukban afejezetekben, használatukon keresztül kerülnek meghatározásra. A tágabb keretet pedig politikaiszükségességük, tehát a romaképek használati módjainak (keletkezés- és fogadtatástörténet),valamint a filmkészítésnek mint hatalmi gesztusnak az elemzése jelenti.

Jól látható az (an)archeológiai módszer múködése a harmadik fejezet (III. A másság vetített képei. A romák kriminalizálásának eszközei) felépítésében is, ahol Pócsik egy elveszett, csak leírásokból ismert 1908-as filmhíradót állít produktív párhuzamba a több mint száz évvel késôbbi, 2009-es Szíven szúrt ország (Babos Tamás et al., 2009) címú filmmel. A filmes újrajátszás, a búntett mozgóképes rekonstrukciójának módszereire fókuszálva a szerző rámutat, hogy mindkét „[...] film a maga hatáskelto【eszközeivel elmossa nemcsak a bûncselekmény kontextusát, hanem a dokumentum és fikció közötti különbségeket is” egy többségi, nem-cigány közönség számára, majd a „bún fogalmát egy elenyészô kisebbség életmódján keresztül kiterjeszti a társadalmi hierarchia alján elhelyezkedô, ám a maihoz hasonlóan rétegzett, közösséget nem alkotó, tehát megfelelô érdekképviselettel sem bíró csoportra" (119). Noha a két film elkészülése között eltelt hosszú idô következtében formai összehasonlításuk megkérdôjelezhetô lenne, Pócsik szövegében a mozgóképek mint emlékezetalakzatok elevenednek meg, amelyeknek a reprezentációs szerepénél sokkal fontosabb a „hatalmi politikákat kiszolgáló propagandaként” (128) történô elemzésük.

A negyedik fejezettól kezdve a kötet elhagyja a komparatív szerkesztési elvet és egy-egy adott audiovizuális szöveget kontextualizál. Erre az irányváltásra véleményem szerint reflektálnia kellett volna a szövegnek még akkor is, ha a módszer körvonalai hasonlóak maradnak. A törésben tetten érhetố a kötet genealógiája, a szerzô érdeklődésének változása, amelyet Pócsik a bevezetôben elôre jelez: a korai fejezetek összehasonlító módszertana idôben a kötet későbbi fejezetei után készültek 
el. Míg az elsô két fejezet az egymás mellé állított filmek felhasználásának, befogadásának, valamint politikai mobilizációjának elmozdulásait rögzítette, addig a negyedik fejezet (IV . „A világ létra..." A dalkölto【Dankó Pista feltámadása a negyvenes évek mozivásznaì Dankó Pista alakjának a tömegkulturális diszkurzusokban (film, népszínmû) zajló átalakulásait követi. Az ötödik fejezet ( V. Cigányok a hatvanas évek filmmüvészetében. Valóság és képzelet határán) Sára Sándor két filmjére közelít, és a lírai eszközöket használó dokumentumfilm, a Cigányok (1962), illetve az újhullámos elemekkel dolgozó játékfilm, a Feldobott kô (1968) közötti politikai hangsúlyeltolódásokat vizsgálja. A szerző azt kívánja megmutatni, hogy a korszakban kialakult modernista, szerzői filmes nyelvezet kialakulása milyen kapcsolatban állt a szocialista állam civilizatorikus, paternalista megközelítésével, amely a filmek „ötvenesévek” felidézésében érhetô tetten (162). Pócsik úgy érvel, ennek a viszonynak kulcsszerepe volt abban, hogy a cigányság áldozatként való bemutatásának konvenciórendszere kialakult (155). „Nem az alkotói eredetiség megkérdójelezése a célom, hanem annak igazolása, hogy ami a szubjektív szerzôi attitûd markáns megnyilatkozása is, egyidejúleg a filmkészítésben rejlô hatalomgyakorlás egy újabb változata" (172) - mutat rá a szöveg.

Az elsố két analitikus fejezet és az utána következő elemzések közötti, fent jelzett elmozdulás a szöveg konceptuális fókuszára is igaz. Ugyanakkor látszik, hogy a negyedik fejezettôl kezdve a fô elméleti kérdések a kötetben nem igazán következetes módon használt modell-motívum-téma probléma köré rendeződnek. Ahogy azt a szerző a hatodik fejezet (VI. „Én, Cséplö György”. A szociológiailag meghatározott valóság és a filmnyelvileg konstruált képzelet határán) végén kifejti,

a játékfilmes példákban a cigány sajátosság a modell jelleget erôsítette: a cigány származású hôs valamilyen, az alkotó számára létezô probléma „illusztrálásaként”, „színesítéseként” szerepelt, a motivikus elemek, az adott életmegnyilvánulások (antropológiai, társadalomtörténeti tényezốk) önkényesen, adott célok érdekében kerültek felhasználásra és maradtak valójában láthatatlanok. (263)

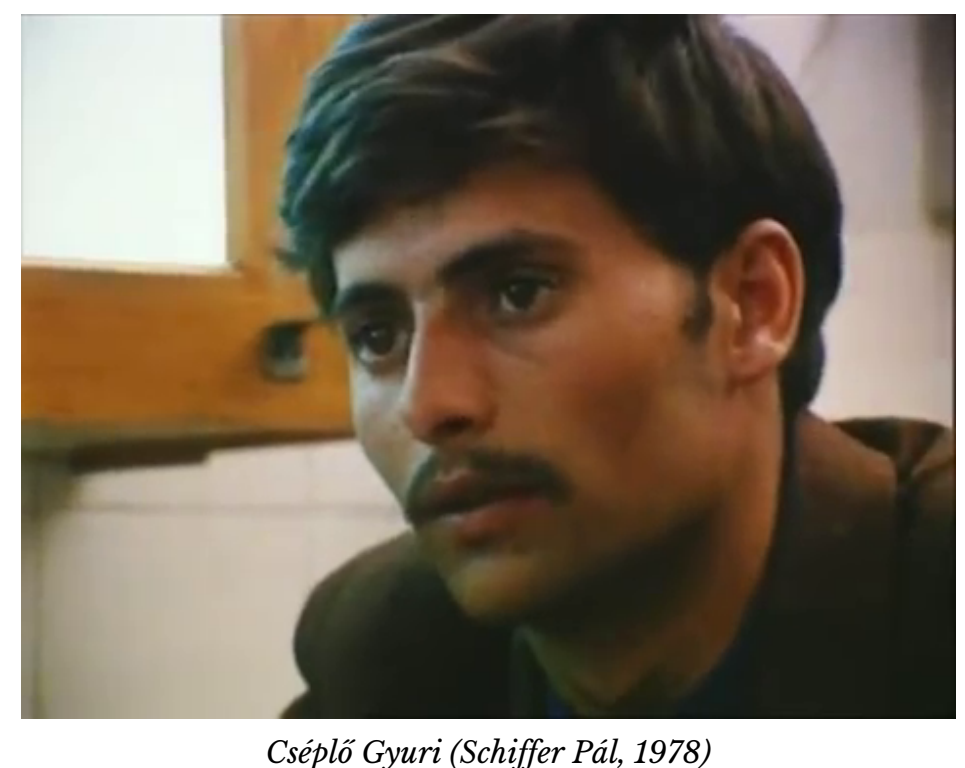

Ez az áthangolódás fontos szerepet kap a kötet leghosszabb, Schiffer Pál Cséplö Gyuri (1978) címú 
munkáját elemző fejezetében. Itt a Sára-filmek „ötvenesévek” reprezentációjához, a homogenizáló áldozatnarratívák modernista ábrázolásához képest már a társadalmi mobilitás lehetôségeire, illetve ezeknek a lehetôségeknek a propagandisztikus tömegkommunikációban történô megjelenésére összpontosítanak az elemzések. Pócsik amellett érvel, hogy Schiffer a dokumentarista eszközök használatával a hivatalos „társadalmi felemelés-felemelkedés” narratívát igyekezett bonyolítani. A rendezô „a fôhoôs cigány fiatalembert a kívülálló megfigyelô hatalmával ruházza fel, az o【tapasztalatain keresztül, az általa megfogalmazott összefüggésben alakul a szegénységképünk" (267). A film így cizellálja a leegyszerúsítő, egy széles társadalmi probléma modelljéül szolgáló romaképek hagyományát, mutat rá a könyv. Schiffer átkelése tehát a saját korábbi munkáihoz képest történő szerzôi-, valamint szereplői szubjektumpozícióinak áthangolódásában érhetố tetten. A Cséplő Gyuriról és a kor cigányábrázolásairól, valamint szociológiai kutatásairól szóló fejezet nem csak a leghosszabb, hanem talán éppen emiatt a leggazdagabb is: különösen a Cigány „önmeghatározások” a Kádár-kor tömegkommunikációjában címú alfejezetben látszanak a mozgóképes diszkurzusok és a politikai retorika összefonódásainak bonyolult módozatai - a Schiffer-film vonatkozásában. Az (an)archeológiai módszer, azaz a rendhagyó (talán „történetietlen”) átkelések követésének ezekben a szövegrészekben különösen jól látszik a hozadéka: segítségükkel olyan egymástól eltérô diszkurzusokat tud produktív dialógusba hozni a szerzô, amelyekből újszerú emlékezetpolitikai összefüggések bontakoznak ki. Ezek az összefüggések írják meg a kötet retrospektív módszertanát.

Az Átkelések a szerzô doktori kutatásából nôtte ki magát. Pócsik a bevezetôben jelzi: meg kellett haladnia azt a nem-reflektált, történeti álláspontot a roma képek elemzésével kapcsolatban, amely a szöveg korábbi verziójára jellemző volt. Ez fôleg azt jelenti, hogy úgy véli, a disszertáció nem explikálta: saját kutatói pozíciója hogyan változtatta meg a kutatás tárgyához való viszonyulását, tehát saját átkeléseit. A most megjelent kötetben önreflexív módon pontosan kirajzolódnak a szerzố pozíciójának elmozdulásai, amelyek adott pontokon töredezetté teszik a retrospektív módon feltáruló kutatói módszereket. Ugyanakkor éppen ezeken a töréseken szûrôdik át a kötet súlyos politikai aktualitása: ma ugyanúgy, mint az 1908-as dánosi gyilkosságot rekonstruáló film esetében, az etnikai sztereotípiák (audiovizuális) terjedésének megértése és kritikai körülbástyázása az egyik legfontosabb kihívás a magyar társadalom számára.

1. David Bordwell: Slajoj Zizek: Say Anything. David Bordwell's website on cinema. 2005. április http://www.davidbordwell.net/essays/zizek.php (Utolsó letöltés: 2017. október 13). Itt fontos kiemelni, hogy nem Bordwell és Žižek vitájában kívánok állást foglalni, inkább az elôbbi szerzôt parafrazeálom egy jelenség azonosítására.

\section{Irodalomjegyzék}

- Bordwell, David: Slajoj Zizek: Say Anything. David Bordwell's website on cinema. 2005. április http://www.davidbordwell.net/essays/zizek.php (Utolsó letöltés: 2017. október 13)

- Pócsik Andrea: Atkelések. A romaképkészités (an)archeológiája. Budapest, Gondolat Kiadó, 2017. 


\section{Filmográfia}

- Cigányok (Sára Sándor, 1962)

- Cséplö Gyuri (Schiffer Pál, 1978)

- Feldobott kố (Sára Sándor, 1968)

- Kék fény (Das blaue Licht. Leni Riefentsahl és Balázs Béla, 1932)

- Sziven szúrt ország (Babos Tamás et al., 2009) 
(C) Apertúra, 2017. Ỗsz | www.apertura.hu

webcím: https://www.apertura.hu/2017/osz/strausz-kulturakutatas-mint-retrospektiv-

$\underline{\text { modszertan/ }}$

https://doi.org/10.31176/apertura.2018.13.1.8

(Q)opertúro 